\title{
SEED GERMINATION AND SEEDLING VIGOUR OF ITALIAN RYEGRASS, COCKSFOOT AND TIMOTHY FOLLOWING HARVEST AND STORAGE
}

\author{
Germinação de sementes e o vigor de plantas jovens de azevem italiano, \\ dactilis e timóteo após a colheita e o armazenamento
}

\author{
Rade Stanisavljević1, Dragoslav Đjokić1, Jasmina Milenković1, Lana Đukanović², \\ Vladeta Stevović ${ }^{3}$,Aleksandar Simic ${ }^{4}$, Dejan Dodig ${ }^{5}$
}

\begin{abstract}
During post-harvest maturation, different species vary in the length of dormancy breaking or germination increases. Seed dormancy and slow seedling development often limit establishment of forage grass stands. Seed germination and seedling vigour of Italian ryegrass (Lolium italicum A. Braun, Synonym Lolium multiflorum L.), cocksfoot (Dactylis glomerata L.) and timothy (Phleum pretense L.) were observed after harvest and storage. After harvest in June, seeds were stored under standard storage conditions and sampled every 30 days after harvest (DAH), up to $270 \mathrm{DAH}$, and then every 60 days up to $990 \mathrm{DAH}$. At each date, seeds were tested for final germination percentage and for seedling vigour traits. Timothy seeds had a maximum germination (88\%) and the best seedlings vigour at $90 \mathrm{DAH}$, which implies that early autumn (September-October) is the best sowing period for freshly harvested seeds of timothy. Timothy seed germination was poor from 270 DAH (73\%). The best germination and vigour of Italian ryegrass and cocksfoot seedlings were between 270 and $330 \mathrm{DAH}$, which equates to spring sowing time (March-April) in the succeeding year. Cocksfoot and Italian ryegrass seeds maintained satisfactory germination levels up to $630 \mathrm{DAH}(81 \%)$ and 810 DAH $(81 \%)$, respectively. The data can serve for the determination of a proper storage duration management between harvest and sowing of the tested species under ambient conditions of south-eastern Europe.
\end{abstract}

Index terms: Forage grasses, post-harvest maturation, seed dormancy.

\section{RESUMO}

Durante o armazenamento, diferentes espécies comportam-se diferentemente quanto à dormência e crescimento de plântulas. A dormência o desenvolvimento lento das plântulas limitam a época do plantio das gramíneas forrageiras plurianuais. A germinação de sementes e o crescimento das plântulas de azevem italiano (Lolium italicum A. Braun sin. Lolium multiflorum L.), Dactilis (Dactilis glomerata L.) e de timoteo (Phleum pratense L.) foi pesquisada durante a maturação pós-colheita e a silagem. Após a colheita, em junho, sementes foram armazenadas em condições tradicionais e analisadas a cada 30 dias após a colheita, até 270 dias e, em seguida, a cada 60 dias até 990 dias. Nessa pesquisa, avaliou-se a germinação final e o vigor das plântulas. As sementes de timoteo obtiveram germinação máxima (88\%) e o melhor crescimento das plântulas após 90 dias de armazenamento, indicando que o melhor período para o plantio das sementes colhidas em junho é o inicio de outono (setembro-outubro). A germinação de sementes de timoteo reduziu nos 270 dias (73\%) seguintes. A melhor germinação, e crescimento da plântula do azevem italiano e do dactilis ocorreu entre 270 e 330 dias, indicando que a melhor época para plantio é na primavera (março-abril), do ano seguinte. As sementes de dactilis e azevem italiano mantiveram germinação satisfatória até 630 dias $(81 \%)$ e 810 dias $(81 \%)$, respectivamente. Essa pesquisa pode servir para determinação de gerenciamento adequado de duração de armazenamento entre a colheita e o plantio das espécies testadas em condições de armazenamento no sudeste da Europa.

Termos para indexação: Gramíneas forrageiras; maturação pós-colheita; dormência de sementes.

(Received in may 17, 2011 and approved in august 22, 2011)

\section{INTRODUCTION}

Italian ryegrass, cocksfoot and timothy are important grasses in temperate agriculture that provide forage for ruminants. Italian ryegrass is native to Europe and neighbouring countries with a temperate climate. Lolium species account for about $23 \%$ of the 52 million ha of grassland in Europe with Italian ryegrass being the most prevalent species (HUMPHREYS et al., 2010). Cocksfoot is used mainly in southern Europe and the USA (WILKINS; HUMPHREYS, 2003). In the Western Balkans (south-east

\footnotetext{
Institute for Forage Crops - Kruševac - Republic of Serbia

${ }^{2}$ High School for Agriculture - Šabac - Republic of Serbia

${ }^{3}$ University of Kragujevac - Cacak - Republic of Serbia

${ }^{4}$ University of Belgrade - Belgrade-Zemun - Republic of Serbia

${ }^{5}$ Maize Research Institute Zemun Polje - Slobodana Bajića 1 - 11185 Belgrade-Zemun - Republic of Serbia - ddodig@mrizp.rs
}

Ciênc. agrotec., Lavras, v. 35, n. 6, p. 1141-1148, nov./dez., 2011 
Europe) cocksfoot performs well in the 50:50 mixtures with alfalfa (LAZAREVIĆ et al., 2006) or under sheep grazing (HAVRANEK et al., 2000). This species can be also used in revegetation of limestone quarries in semi-arid regions (ABRAHAM et al., 2009). Timothy is native to Europe and temperate Asia, but it has been introduced to most temperate areas, cultivated as a hay and pasture grass. In south-east Europe tymothy annual yields range from 7.5-13.0 t dry matter $\mathrm{ha}^{-1}$, in continuous cropping or in the mixture with legumes (TOMIĆ et al., 2007), up to $15.7 \mathrm{t}$ dry matter $\mathrm{ha}^{-1}$ in the mixture with bird's-foot trefoil (CHURKOVA, 2010).

A high percentage of seeds of cultivated grasses are either dormant or fail to germinate after harvest or dispersion under natural conditions. Seed dormancy has been reduced in some intensively cultivated agricultural crops, mainly vegetables, through breeding. However, seed dormancy in cultivated forage species is very pronounced and very similar to dormancy of seeds of these species in meadow communities (ADSKIM et al., 2002). Seed dormancy is undesirable when meadows and pastures are established, as it reduces establishment. However, seed dormancy and delayed germination of forage grasses under natural conditions can be beneficial because they postpone germination and the initial growth of seedlings until environmental conditions improve (STANISAVLJEVIĆ et al., 2010b).

Maximum germination is achieved after the period of seed maturation and dormancy loss. Further seed storage leads to certain physiological and biochemical processes that result in seed ageing and germination decreases (BEWLEY; BLACK, 1994). Seed germination conservation in the course of ageing depends largely on the plant species (WALTERS et al., 2005) as well as on storage conditions (WALTERS et al., 2004).

The objective of the present study was to determine changes in seed germination and seedling vigour in Italian ryegrass, cocksfoot and timothy during post-harvest maturation and ageing of seed. We used ambient store conditions as typical way of keeping certified seed stocks in south-eastern Europe. The implications of the results for storage management and establishment of new pasture are discussed.

\section{MATERIAL AND METHODS}

\section{Seeds}

The experiment was set up with seeds of the cultivar K-13 (Italian ryegrass), K-40 (cocksfoot) and K-15 (timothy), which are summer-active (continental cultivars). All three cultivars have originated from local populations and been developed in Serbia. The seeds were collected at full maturity in mid-June 2007 and mid-June 2008 from twoyear-old production fields in the vicinity of the city Zajeèar,

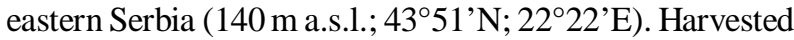
seeds were cleaned manually, placed into paper bags and stored dry under ambient storage conditions (Table 1). Seed samples were drawn every 30 days starting immediately after harvest up to 270 days after harvest (DAH), and then every 60 days up to $990 \mathrm{DAH}$.

\section{Germination}

After each of the storage periods, four replicates of 100 seeds of each cultivar were germinated on filter paper (TP) according to the ISTA Rules (ISTA, 2008). After a chilling treatment for five days at $5^{\circ} \mathrm{C}$, the seeds were germinated at alternating temperatures of $25 / 15^{\circ} \mathrm{C}\left(25^{\circ} \mathrm{C}\right.$ for $8 \mathrm{~h}$ in light and $15^{\circ} \mathrm{C}$ for $16 \mathrm{~h}$ in dark). The final seedling count was made after 14 days for all three cultivars. In addition, the primary root length $(\mathrm{cm})$, shoot length $(\mathrm{cm})$ and fresh seedling biomass (root + shoot, mg) were measured after the final count. The seedling length was measured using a ruler. The moisture content of seed samples was measured thermo gravimetrically at $130^{\circ} \mathrm{C}$ to constant weight (ISTA, 2008).

\section{Statistical analysis}

The data were analyzed by two-way ANOVA and regression method using SPSS version 11.0 (SPSS inc., USA) and STATISTICA version 8 (StatSoft, Inc. Tulsa, OK, USA) software, respectively. LSD multiple range test was used to detect significant differences among means at the $5 \%$ level of probability. To correct for non-normality the statistical analysis was done on arcsine transformed values for final germination.

\section{RESULTS AND DISCUSSION}

The harvested seeds were stored dry at about $12 \%$ moisture content under ambient storage conditions. The initial quality of the used seed, as reflected in mean 1000 seed weight immediately after harvest, can be considered satisfactory for Italian ryegrass $(2.14 \mathrm{~g})$, cocksfoot $(1.10 \mathrm{~g})$ and timothy $(0.44 \mathrm{~g})$. Namely, under environmental conditions of Serbia weight of 1000 seed typically ranges in Italian ryegrass from 1.6 to $2.5 \mathrm{~g}$, in cocksfoot from 0.8 to $1.3 \mathrm{~g}$ and in timothy from 0.3 to $0.5 \mathrm{~g}$ (MILADINOVIĆ, 2001). The mean monthly air temperature and relative humidity during storage varied from $2^{\circ} \mathrm{C}$ (January) to $23^{\circ}$ $\mathrm{C}$ (August) and from 63\% (June) to $81 \%$ (January), respectively (Table 1 ). Although the temperature and relative air humidity varied during storage, these values more or less represent common conditions of seed storage in the continental part of south-eastern Europe. 
The results on the germination test and seedling traits for Italian ryegrass, cocksfoot and timothy after different durations of storage are shown in Figures 1,
2 and 3, respectively. The initial germination of Italian ryegrass seeds after harvest was $58 \%$ and did not increase $(P<0.05)$ until 90 DAH $(67 \%)$ (Figure 1$)$.

Table 1 - Average, maximum and minimum temperatures and relative air humidity of room during storage period.

\begin{tabular}{lcccccc}
\hline \multirow{2}{*}{ Month } & \multicolumn{3}{c}{ Temperature $\left({ }^{\circ} \mathrm{C}\right)$} & \multicolumn{3}{c}{ Relative air humidity $(\%)$} \\
\cline { 2 - 7 } & Average & Minimum & Maximum & Average & Minimum & Maximum \\
\hline January & 2 & 1 & 3 & 81 & 75 & 86 \\
February & 6 & 3 & 9 & 79 & 70 & 87 \\
March & 9 & 4 & 13 & 78 & 68 & 87 \\
April & 11 & 6 & 15 & 66 & 49 & 83 \\
May & 13 & 7 & 18 & 65 & 47 & 82 \\
June & 20 & 15 & 24 & 63 & 45 & 80 \\
July & 22 & 16 & 30 & 64 & 48 & 80 \\
August & 23 & 17 & 31 & 68 & 52 & 84 \\
September & 12 & 9 & 23 & 74 & 65 & 82 \\
October & 11 & 5 & 17 & 76 & 68 & 84 \\
November & 6 & 2 & 10 & 77 & 70 & 83 \\
December & 3 & -1 & 5 & 79 & 72 & 85 \\
\hline
\end{tabular}
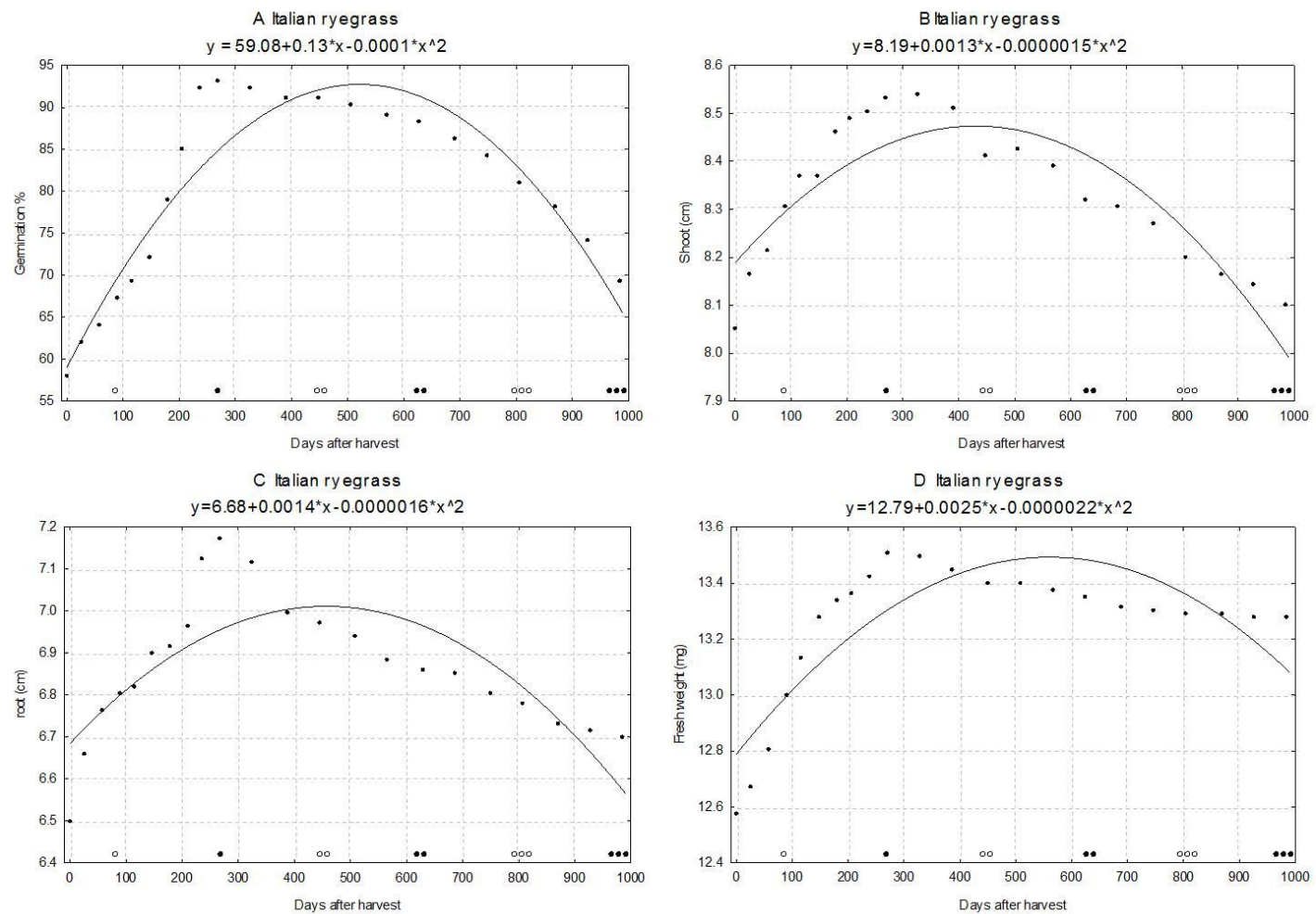

Figure 1 - Percentage of Italian ryegrass seed germination (A), seedling shoot length (B), seedling root length (C) and seedling fresh weight (D) after various lengths of dry storage (2007 and 2008 combined). $\diamond, \circ,, \circ \circ$, autumn (September) sowing time in the year of harvest, in the first and in the second year after harvest in June, respectively.•, $\bullet \bullet, \bullet \bullet$, spring (March) sowing time in the first, second and third year after harvest in June, respectively.

Ciênc. agrotec., Lavras, v. 35, n. 6, p. 1141-1148, nov./dez., 2011 

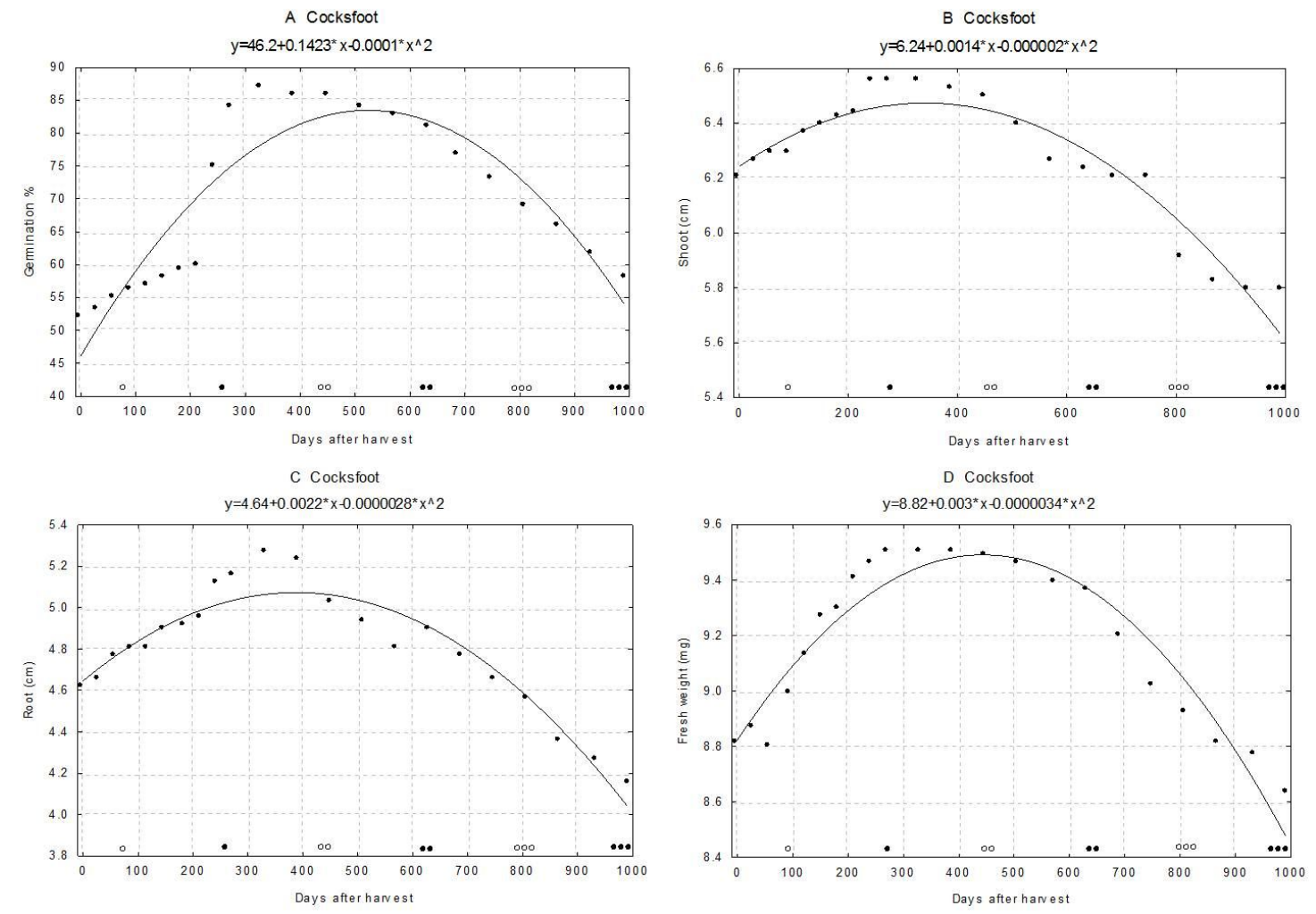

Figure 2 - Percentage of cockfoot seed germination (A), seedling shoot length (B), seedling root length (C) and seedling fresh weight (D) after various lengths of dry storage (2007 and 2008 combined), ,,,$\circ \circ$, autumn (September)

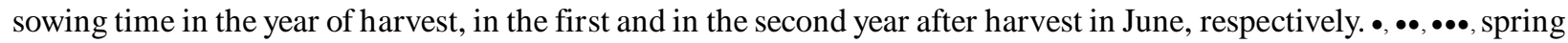
(March) sowing time in the first, second and third year after harvest in June, respectively.

An increase $(P<0.05)$ in germination occurred between 150 DAH and $180 \mathrm{DAH}(72 \%$ vs. $79 \%)$, indicating the start of dormancy loss. Germination constantly increased from 180 DAH (79\%) to 240DAH(92\%), but was maximized by 270 DAH $(93 \%)$. A constant reduction in final germination of Italian ryegrass seed was recorded from $330 \mathrm{DAH}$ (Figure 2). However, the major reduction of final germination did not occur before 750 DAH $(84 \%)$, while satisfactory germination, in a sense of the market requirement, was up to $870 \mathrm{DAH}(78 \%)$. At the end of the sampling period (990 DAH), final germination was $69 \%$. Although there was a constant reduction in the seedling vigour during seed ageing of Italian ryegrass, this reduction was only significant for the root length. The reduction $(p<0.05)$ of the root length occurred-on 870 DAH (Figure 1).

The initial germination of cocksfoot seed after harvest was only $52 \%$ and the final germination constantly increased up to 330DAH (87\%) (Figure 2). As with Italian ryegrass, the germination increase $(P<0.05)$ occurred on
90 DAH $(56 \%)$. However, the major dormancy-breaking effect of after-ripening obviously occurred between 210 and $270 \mathrm{DAH}$. This lead to an increase $(P<0.05)$ of final germination between two consecutive after-ripening dates $(60 \%$ vs. $75 \%)$. Final germination also increased $(P<0.05)$, by $9 \%$, between 240 and $270 \mathrm{DAH}$, and after that the increase between two consecutive after-ripening dates was no longer significant. A reduction $(P<0.05)$ in the final germination of cocksfoot occurred after ten months (630 $\mathrm{DAH})$ when it decreased from its peak of $87 \%$ down to $81 \%$ (Figure 3). Germination decreased faster from $630 \mathrm{DAH}$ to reach a final germination of $58 \%$ on $990 \mathrm{DAH}$. The reduction $(P<0.05)$ of the shoot length, root length and seedling biomass occurred after $810 \mathrm{DAH}$ for the shoot length and $750 \mathrm{DAH}$ for the root length and seedling biomass (Figure 2).

Timothy had the highest initial seed germination of $62 \%$ (Figure 3 ). The after-ripening period for timothy seeds was completed only after $90 \mathrm{DAH}$, when maximum 

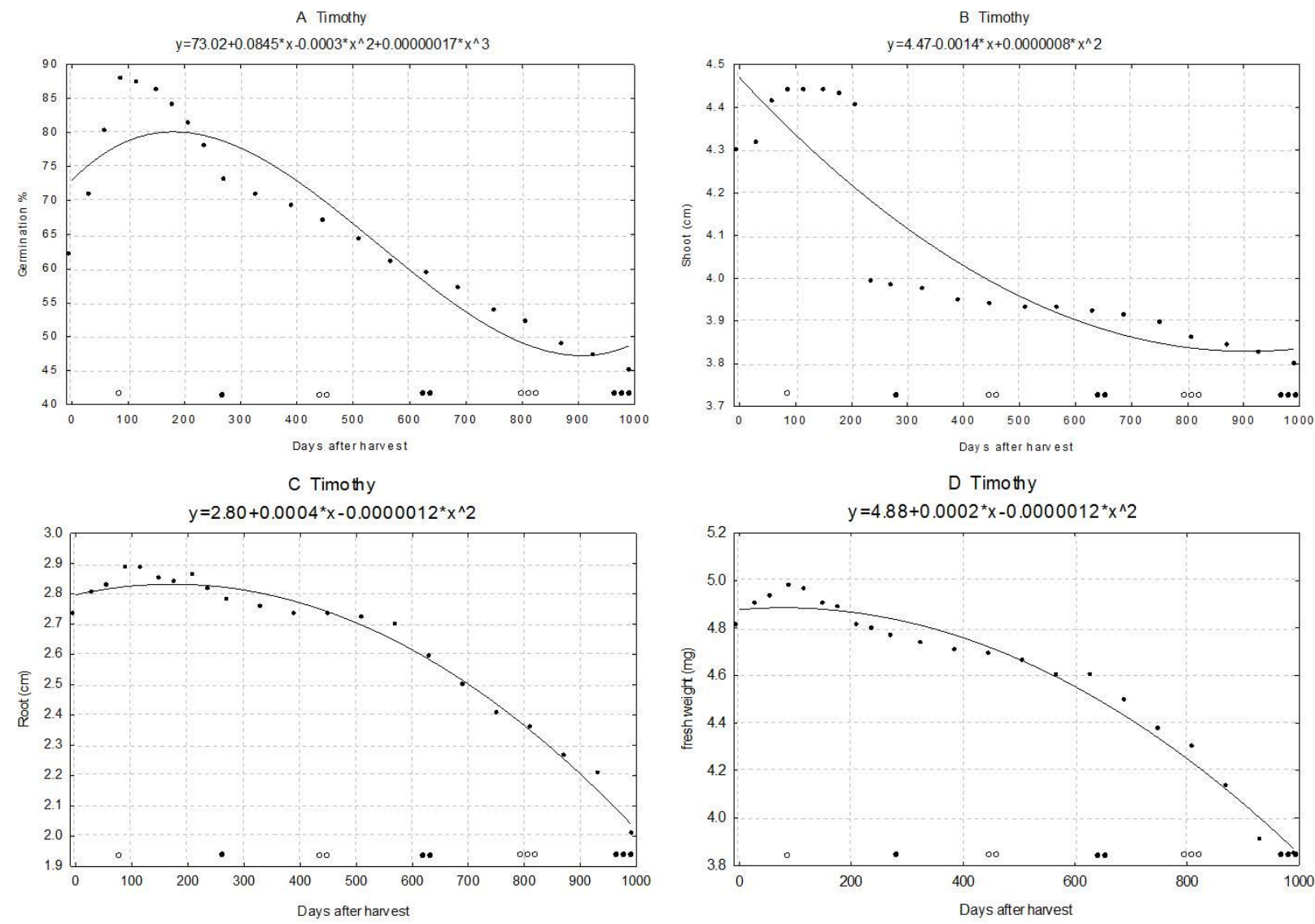

Figure 3 - Percentage of timoty seed germination (A), seedling shoot length (B), seedling root length (C) and seedling fresh weight (D) after various lengths of dry storage (2007 and 2008 combined)॰, ০, , ০, autumn (September) sowing time in the year of harvest, in the first and in the second year after harvest in June, respectively. sowing time in the first, second and third year after harvest in June, respectively.

germination occurred (88\%) (Figure 3). A start of dormancy loss can be assigned to $30 \mathrm{DAH}$ when final germination increased $(P<0.05)$ by $9 \%$ compared to germination immediately after harvest. Final germination also increased $(P<0.05)$ between 30 and $60 \mathrm{DAH}$, as well as, 60 and 90 DAH, by $9 \%$ and $8 \%$, respectively. Timothy seed showed a reduction $(P<0.05)$ in the final germination after only six months (180 DAH) (Figure 3). Satisfactory germination was maintained up to $240 \mathrm{DAH}(78 \%)$, however, after $570 \mathrm{DAH}$ germination was similar to immediately after harvest (62\%), and at the end of the sampling period (990 DAH) it had dropped to only $45 \%$. The reduction $(P<0.05)$ in seedling vigour occurred after 270, 630 and $510 \mathrm{DAH}$, respectively (Figure 3).

All three species showed moderate levels of seed dormancy immediately after harvest with 52\%-62\% germination. The results proved the requirement for ripening of the seeds to breakdown dormancy of all three species. In our work, ripening during storage improved final germination up to $93 \%$ in Italian ryegrass, $89 \%$ in cocksfoot and $88 \%$ in timothy. Storage also improved seedlings vigour in all three species, although not always significantly. High germination and rapid seedling development are prerequisites for successful pasture or sward establishment (SOUZA SOBRIHNO et. al., 2008; LAURAet. al., 2009; KOJOROSKI-SILVA et. al., 2011). Grass seed dormancy immediately after harvest or seed dispersal under natural conditions is pronounced and can be based on tissues surrounding the embryo (ADKINS et al., 2002), or due to the embryo itself (DYER et al., 1993). Seed dormancy and additional germination is generally undesirable, but under natural conditions with a pronounced winter period, such as in the continental part of south-eastern Europe, additional germination from

Ciênc. agrotec., Lavras, v. 35, n. 6, p. 1141-1148, nov./dez., 2011 
dormant seeds can be useful. Under such conditions, germination and the initial growth of seedlings are postponed till spring when environmental conditions are more favourable, which positively affects the maintenance of forage grasses in meadow communities (STANISAVLJEVIĆ et al., 2010b).

In continental regions of south-eastern Europe, perennial forage grass seeds are harvested or dispersed under natural conditions mainly in June. Harvested seeds can be used to establish new crop by sowing in autumn (August-September) of the same year or in spring (MarchApril) of the succeeding year. Sowing in the harvest year results in satisfactory forage yields. However, spring sowing in the year that succeeds the harvest year results in a lower $(P<0.05)$ fodder yield, while there is no seed yield at all or it is minimal (STANISAVLJEVIĆ et al., 2008). Laws and regulations governing the seed trade in the countries of south-eastern Europe mainly determine minimum germination standards (hereafter referred as satisfactory germination) of approximately $70-75 \%$. The patterns of germination and of the seedling vigour measured in this study provide aspects for recommendation the best sowing date and, in particular, about the minimum and maximum storage period between harvests and sowing of Italian ryegrass, cocksfoot and timothy.

Although the germination of Italian ryegrass seeds increased $(P<0.05)$ after 90DAH (from 58 to $67 \%$ ), satisfactory germination of about 70-75\% occurred between 150 and 180 DAH(November-December). Sowing between November and March is not practicable because of low soil temperatures and frost. On the other hand, maximum germination and seedling vigour occurred after the 270 DAH (March). Thus, early spring (April) sowing seems to be the best sowing period for freshly harvested Italian ryegrass seeds.

Cocksfoot seeds also had unsatisfactory germination for sowing in autumn (September) of the same year, because only $56 \%$ of seeds germinated after 90 days. The dormancy of cocksfoot seeds began to decrease between 210 (January) and 240 DAH (February) and reached a high level of germination (84-87\%) by $270-330$ DAH (March-May). Their seedling vigour traits were also highest at this time. Thus, the results suggest early spring (April) as the most suitable period for cocksfoot sowing.

Timothy seeds began to lose dormancy from 30 DAH (July) and reached satisfactory germination (80\%) by 60 DAH (August). The highest germination (87-88\%) and the seedling vigour traits were attained from 90 and 120 DAH, corresponding to September and October, respectively. This suggests early summer in the year of seed harvest as the most suitable period for timothy sowing.
The duration of seed dormancy varied among species ranging from one month for timothy through to seven months for cocksfoot. This was expected as these species belonged to different genera and because of previous reports in the literature. However, seed dormancy duration does vary among species belonging to the same genus. For instance, studies on post-harvest seed maturation in the most important forage species of the genus Festuca show that dormancy varied from 60 days (Festuca arundinacea Schreb.) to 90 and 120 days in Festuca rubra L. and, Festuca pratensis Huds. respectively (STANISAVLJEVIĆ et al., 2010a).

Seeds reach maximum germination during storage, but if storage is prolonged germination is decreased and lost (RAJJOU et al., 2008), which signifies the process of seed ageing. Low humidity and low temperatures in storage prolong germination (WALTERS et al., 2004). A reduction $(P<0.05)$ in seed germination (from $92 \%$ to $84 \%)$ of Italian ryegrass was not recorded before 750 DAH. Furthermore, acceptable germination was recorded up to $810 \mathrm{DAH}(81 \%)$ and without a reduction $(P<0.05)$ of the seedling vigour. In practice, there may also be also interest in storing the seeds of Italian ryegrass over the next two autumn sowings.

A reduction $(P<0.05)$ in cocksfoot seed germination (from $87 \%$ to $81 \%$ ) was not recorded until 630 DAH. Final germination was still satisfactory (over $70 \%$ ) for the next six months, but thereafter, seed germination dropped below $70 \%$ and the seedling vigour decreased $(P<0.05)$. This species should not be considered for autumn sowing in the second year after seed harvest until the seed has been stored under conditions that extend seed quality.

Unlike Italian ryegrass and to a lesser degree cocksfoot, seed germination $(69 \%)$ in timothy was unsatisfactory for sowing from $390 \mathrm{DAH}$. The last sowing date that should be considered was 270-300 DAH, which aligns with spring sowing in the succeeding year after harvest (March-April). In comparison with the other two species, shoot and primary root length, as well as seedling biomass, is lower in timothy. This partly agrees with MOOT et al. (2000), who stated that the weight of a dry embryonic stem after 57 days amounted to $67.9 \mathrm{mg}, 34.5 \mathrm{mg}$ and 35.6 $\mathrm{mg}$ in Italian ryegrass, cocksfoot and timothy, respectively. The difference is that Moot and co-workers found cocksfoot to be as low as timothy.

In timothy, the decrease in the length of seedling primary roots and especially of embryonic shoots occurred much earlier than for shoot biomass. The radicle growth immediately after germination is very important for successful crop development. A reduced growth of radicles from older seeds was also recorded in maize (SVEINSDÓTTIR et al., 
2009) and wheat (SPANO et al., 2007), as it was associated with a reduction of cell division and expansion in the radicle growth zone. However, little data has been gathered on physiological mechanisms regulating reduced radicle growth during seed ageing. Studies on leading forage grasses of the genus Festuca and Arrhenatherum elatius also showed that the period of poorer seed germination is followed by a weaker growth of the embryonic shoot, radicle and seedling weight (STANISAVLJEVIĆ et al., 2010a; 2010c).

\section{CONCLUSION}

Improved final germination and seedling size traits were observed during seed storage in all three species. A reduction $(P<0.05)$ in dormancy was found 30,180 and 240 DAH for timothy, Italian ryegrass and cocksfoot, respectively. At least three (timothy), nine (Italian ryegrass) and 11 months (cocksfoot) of ripening were required for maximum germination and seedling vigour. The results indicate that in temperate regions early autumn is the best sowing period for freshly harvested seeds of timothy, while early spring is the best sowing period for Italian ryegrass and cocksfoot. Italian ryegrass seeds can be used for sowing up to 810 DAH (germination c. $81 \%$ ); cocksfoot seed can be used up to 630 DAH (germination c. $81 \%$ ), while timothy seeds can be used up to $270 \mathrm{DAH}$ (germination c. $73 \%$ ). These obviously can be extended if they have good storage conditions e.g. low temperatures and low humidity.

\section{ACKNOWLEDGEMENTS}

To the Ministry of Science and Technology of the Republic of Serbia for financial support (Grant 20048).

\section{REFERENCES}

ABRAHAM, E.M.; KOSTOPOULOU, P.; KOUKOURA, $Z$. Establishment and survival of different legume and grass species and cultivars at a limestone quarry in Greece. Arid Land Research and Management. Philadelphia, v.23, n.3, p.183-196, 2009.

ADKINS, S.W.; BELLAIRS, S.M.; LOCH, D.S. Seed dormancy mechanisms in warm season grass species. Euphytica, Wageningen, v.126, n.1, p.13-20, 2002.

BEWLEY, J.D.; BLACK, M. Seeds: physiology of development and germination. New York, 1994. 445p.

CHURKOVA, B. Study of introducent meadow grasses in mixtures with bird's foot trefoil under the agro- ecological conditions of Troyan. Biotechnology in Animal Husbandry, Belgrade, v.26, n.2, p.429-434, 2010.

DYER, W.E. Dormancy-associated embryonic mRNA's and proteins in imbibing Avena fatua caryopses.

Physiologia Plantarum, Copenhagen, v.88, n.2, p.201$211,1993$.

HAVRANEK, D.; GRBEŠA, D.; KNEŽEVIĆ, M. The influence of fed in sheep on preferability of vegetative growth of different kinds of grass. Agriculturae Conspectus Scientificus, Zagreb, v.65, n.4, p.187-197, 2000.

HUMPHREYS, M. et al. Ryegrasses. In: BOLLER, B.; POSSELT, U.K.;VERONESI, F. Fodder Crops and Amenity Grasses. New York: Springer, 2010. p.211-260.

ISTA. International rules for seed testing. Zurich, 2008. $31 \mathrm{p}$.

KOJOROSKI-SILVA, C.M. et al. Desenvolvimento morfológico das gramas Esmeralda, São Carlos e Tifton 419. Ciência e Agrotecnologia, Lavras, v.35, n.3, p.471477, 2011.

LAURA, V.A. et al. Qualidade física e fisiológica de sementes de braquiárias comercializadas em Campo Grande-MS. Ciência e Agrotecnologia, Lavras, v.33 n.1, p. 326-332, 2009.

LAZAREVIĆ, D. et al. Production potential of artificial grassland in lowland and mountains in Serbia.

Biotehnology in Animal Husbandry, Belgrade, v.22, spec. iss., p.481-489, 2006.

MILADINOVIĆ, M. Seed production of forage crops. Novi Sad: Institute of Field and Vegetable Crops, 2001. 390p.

MOOT, D.J. et al. Base temperature and thermal time requirements for germination and emergence of temperate pasture species. New Zealand Journal of Agricultural Research, Wellington, v.43, n.1, p.15-25, 2000.

RAJJOU, L. et al. Proteome-wide characterization of seed aging in Arabidopsis: A comparison between artificial and natural aging protocols ${ }^{[\mathrm{W}][\mathrm{OA}]}$. Plant Physiology, Minnesota, v.148, n.3, p.620-641, 2008. 
SOUZA SOBRINHO, F. et al. Avaliação do potencial de propagação por sementes de capim-elefante hexaplóide. Ciência e Agrotecnologia, Lavras, v.32, n.3, p.974-977, 2008.

SPANO, C. et al. RNases and nucleases in embryos and endosperms from naturally aged wheat seeds stored in different conditions. Journal of Plant Physiology, Jene, v.164, n.4-5 p.487-495, 2007.

STANISAVLJEVIĆ, R. et al. Quality changes of common cars tail (Phleum pratense L.) and franch raygrass (Arrhernaterum elatior L.) during ripening and correlative dependence of their significant characteristics. Plant Breeding and Seed Production, Belgrade, v.14, n.3-4, p.39-43, 2008.

STANISAVLJEVIĆ, R. et al. Effects of the duration of after-ripening period on seed germinations and seedling size in three fescue species. Spanish Journal of Agricultural Research, Madrid, v.8, n.2, p.454-459, 2010a.

STANISAVLJEVIĆ, R.; SIMIĆ, A.; SOKOLOVIĆ, D. Seed production of perennial forage grasses in Serbia. Biotechnology in Animal Husbandry, Belgrade, v.26, n.2, p.159-172, $2010 b$.
STANISAVLJEVIĆ, R. et al. Desiccation, postharvest maturity and seed aging of tall oat grass. Pesquisa Agropecuaria Brasileira, Brasília, v.45, n.11, p.12971302, 2010c.

SVEINSDÓTTIR, H. et al. Seed ageing-induced inhibition of germination and post-germination root growth is related to lower activity of plasma membrane H+-ATPase in maize roots. Journal of Plant Phisiology, Jene, v.166, n.1, p.128-135, 2009.

TOMIĆ, Z. et al. Perennial legumes and grasses stable source of quality livestock fodder feed. Biotechnology in Animal Husbandry, Belgrade, v.23, n.4-5, p.559-572, 2007.

WALTERS, C.; WHEELER, L.M.; GROTENHUIS, J.M. Longevity of seeds stored in a genebank: species characteristics. Seed Science Research, Wallingford, v.15, n.1, p.1-20, 2005.

WALTERS, C.; WHEELER, L.M.; STANWOOD, P.C. Longevity of cryogenically stored seeds. Cryobiology, San Diego, v.48, n.2, p.229-244, 2004.

WILKINS, P.W.; HUMPHREYS, M.O. Progress in breeding perennial forage grasses for temperate agriculture. The Journal of Agricultural Science, Wageningem, v.140, n.2, p.129-150, 2003. 